Syntax Literate : Jurnal Ilmiah Indonesia p-ISSN: 2541-0849

e-ISSN : 2548-1398

Vol. 5, No. 1 Januari 2020

\title{
FAKTOR-FAKTOR RISIKO PASIEN HEMODIALISIS DI RSUD ARJAWINANGUN DAN RSUD WALED KABUPATEN CIREBON
}

\author{
Dosi Ahmad Yani, Prih Sarnianto dan Yusi Anggriani \\ Universitas Pancasila \\ Email: dosi.ahmadyani@gmail.com,Prih1488@gmail.com dan yusi1777@yahoo.com
}

\begin{abstract}
Abstrak
Penyakit Ginjal Kronis (PGK) merupakan masalah kesehatan dengan insidensi dan prevalensi gagal ginjal yang semakin meningkat, prognosis yang buruk dan biaya yang tinggi. Faktor-risiko PGK beragam menurut kawasan geografi dan era terkait gaya hidup termasuk konsumsi makanan dan atau minuman. Penelitian ini bertujuan untuk mengetahui faktor risiko apa saja yang ada pada pasien PGK yang menjalani hemodialisis di RSUD Arjawinangun dan Waled Kabupaten Cirebon. Jenis penelitian ini adalah penelitian observasional analitik kasus-kontrol. Kelompok kasus (93 responden) adalah pasien PGK yang melakukan hemodialisis, sementara kelompok kontrol (93 responden) adalah pasien rawat jalan selain pasien PGK, dengan kriteria inklusi dan eksklusi tertentu. Data primer diperoleh melalui wawancara menggunakan kuesioner yang dikembangkan oleh Pusat Riset Obat dan Makanan, dan data sekunder diperoleh dari berkas rekam medis pasien. Analisis data yang dilakukan adalah analisis univariat, bivariat (2x2 chi-square) dan multivariat (regresi logistik). Responden penelitian ini mayoritas berjenis kelamin laki-laki (51,6\%), umur rata-rata (minimal-maksimal) 48 (20-75) tahun, status kawin (86\%), pendidikan sekolah dasar atau dibawahnya (49,5\%), pekerjaan membutuhkan fisik (52,7\%), pendapatan sama atau di bawah pendapatan per kapita (57\%). Faktor-faktor risiko yang berhubungan secara bermakna dengan kejadian PGK dalam penelitian ini adalah pekerjaan intelektual (OR 0,104; 95\% CI = 0,018-0,592); riwayat penyakit hipertensi (OR 46,481; 95\% $C I=11,444-188,784)$; riwayat penyakit diabetes mellitus $($ OR 25,239; $95 \% C I=$ 3,680-116,267); konsumsi air putih 1-4 gelas (OR 46,717; 95\% CI = 7,228301,926); sering mengkonsumsi minuman yang mengandung kadar mineral/gula tinggi (OR 3,808; 95\% CI = 1,207-12,012) dan sering mengkonsumsi makanan yang mengandung garam tinggi (OR 10,317; 95\% CI =3,331-31,954).
\end{abstract}

Kata kunci: Faktor Risiko, Penyakit Ginjal Kronis, Hemodialisis

\section{Pendahuluan}

Kesehatan merupakan aspek yang penting dalam menunjang program pembangunan (Evitasari, 2016). Salah satu masalah kesehatan yang banyak dialami masyarakat saat ini adalah Penyakit Ginjal Kronis (PGK). PGK merupakan masalah kesehatan dengan insidensi dan prevalensi gagal ginjal yang semakin meningkat, prognosis yang buruk dan biaya yang tinggi (Hill, Fatoba, Oke, Hirst, O'Callaghan, et al., 2016). 
Prevalensi PGK meningkat bersamaan dengan meningkatnya jumlah penduduk lanjut usia dan jumlah kejadian penyakit diabetes mellitus serta hipertensi. Sekitar 1 dari 10 populasi global mengalami PGK pada stadium tertentu. Hasil penelitian systematic review dan meta-analysis yang telah dilakukan mendapatkan prevalensi global PGK sebesar 13,4\% (Data \& RI, 2017).

Prevalensi tertinggi penyakit gagal ginjal kronis di Indonesia berada di Propinsi Sulawesi Tengah dengan angka i sebesar 0,5 persen, diikuti Aceh, Gorontalo, dan Sulawesi Utara masing-masing 0,4 persen. Propinsi Jawa Barat berada pada posisi berikutnya dengan prevalensi sebesar $0,3 \%$ bersamaan dengan Jawa Tengah, Jawa Timur DI Yogyakarta, Lampung, Nusa Tenggara Timur dan Sulawesi Selatan (K. Kesehatan et al., 2018).

Jumlah penderita baru PGK pada 2007 sebanyak 4.977 orang, dan meningkat menjadi 21.051 orang pada 2015, yang berarti terjadi peningkatan lebih dari 3 kali lipat dalam kurun waktu 8 tahun. Jumlah penderita PGK yang aktif menjalani hemodialisis sebanyak 1.885 orang pada 2007 dan meningkat lebih dari 15 kali lipat menjadi 30.554 orang pada 2015 (K. Kesehatan \& RI, 2013).

Secara global, penyebab PGK terbesar adalah diabetes mellitus, sementara di Indonesia penyebab terbanyak sampai dengan tahun 2000 adalah glomerulonefritis, dan dalam beberapa tahun terakhir penyebab PGK terbanyak berubah menjadi hipertensi (K. Kesehatan \& RI, 2013).

Jumlah penderita baru PGK di Indonesia berdasarkan etiologinya yang terbanyak adalah Penyakit Ginjal Hipertensi sebanyak 44\%, kemudian berikutnya Nefropati Diabetika 22\%, dan Glumerulopati Primer/GNC 8\% melengkapi 3 besar penyebab gagal ginjal (K. Kesehatan \& RI, 2013). Terdapat juga etiologi Lain-lain sebanyak 8\% dan etiologi Tidak Diketahui sebanyak 3\% (K. Kesehatan \& RI, 2013) yang mengindikasikan cukup tingginya kerusakan ginjal akibat penggunaan bahan kimia berbahaya. Beberapa jenis obat dikenal memiliki efek nefrotoksik yang dapat mengurangi fungsi ginjal, seperti antibiotik golongan aminoglikosida yang eliminasinya melalui ginjal (Registry, n.d.), ataupun analgetik dari golongan Anti Inflamasi Non Steroid (AINS) (Chasani, 2008). Obat tersebut terutama NSAID sering digunakan masyarakat tanpa terkontrol melalui peredaran "obat stelan" yang populer di masyarakat karena harganya yang terjangkau (MEE, 2002) (Lifestye.kompas.com., 2016).

\section{Metode Penelitian}

Metode penelitian yang digunakan adalah metode observasional, secara lebih spesifik berupa penelitian case-control. Survei akan dilakukan terhadap sejumlah penderita penyakit ginjal kronis stadium-lanjut di Rumah Sakit Umum Daerah (RSUD) Arjawinangun dan Waled Kabupaten Cirebon.

Populasi penelitian ini adalah seluruh pasien yang mendapatkan pelayanan hemodialisis. Sampel diambil secara purposive sampling berdasarkan kriteria inklusi yang ditetapkan, yaitu: 
1. Umur minimal 18 tahun

2. Telah terdiagnosis PGK stadium-lanjut dan mendapatkan pelayanan hemodialisa di rumah sakit minimal pada 12 bulan terakhir dan maksimal 5 tahun.

3. Pasien dalam kondisi sadar dan memiliki kemampuan kognitif yang memadai untuk memberikan persetujuan dan wawancara lengkap.

4. Tidak sedang mengikuti uji klinis.

Kriteria eksklusi untuk sampel ditetapkan sebagai berikut:

1. Tidak bersedia berpartisipasi dalam penelitian

2. Mengalami penurunan kesadaran

3. Terindikasi mengidap penyakit yang mengancam jiwa, seperti kanker, penyakit jantung berat, stroke.

Responden kontrol dipilih secara acak pada saat pasien antri di bagian pendaftaran. Kriteria kontrol adalah pasien yang mendapatkan layanan kesehatan di poliklinik pada RS yang sama dan belum pernah didiagnosis PGK oleh dokter atau didukung data laboratorium dari rekam medik atau hasil pemeriksaan ulang laboratorium yang menunjukkan nilai $\mathrm{LFG} \geq 60 \mathrm{ml} /$ menit dengan hasil urinalisis normal. Berdasarkan kriteria tersebut di atas, diperoleh sampel atau responden sebanyak 93 orang pada kelompok kasus, sehingga untuk kelompok kontrol juga diambil 93 sampel atau responden.

Pengumpulan data dilakukan melalui wawancara dengan kuesioner terstruktur sebagai instrumen. Instrumen pengumpul data kualitatif yang digunakan dalam penelitian ini adalah kumpulan kuesioner terstruktur yang terdiri dari kuesioner terkait penyakit Gagal Ginjal Kronis yang dikembangkan Pusat Riset Obat dan Makanan (PROM) dari Badan Pengawas Obat dan Makanan (BPOM) Republik Indonesia dengan bantuan sejumlah dokter spesialis penyakit ginjal di Indonesia yang telah divalidasi. Instrumen kuesioner yang akan digunakan dilampirkan dalam bagian akhir thesis ini. Instrumen lainnya adalah lembar pencatatan data biaya dan data lain yang diperlukan dari rekam medis pasien.

Penelitian ini dinyatakan layak untuk dilaksanakan berdasarkan Surat Keterangan Kaji Etik dari Komisi Etik Riset dan Pengabdian Kesehatan Masyarakat Fakultas Kesehatan Masyarakat Universitas Indonesia.

Data yang diperoleh pada penelitian ini akan dianalisis secara statistika menggunakan perangkat lunak SPSS dalam tiga tahapan sebagai berikut:

1. Analisis univariat.

Sebagai analisis tingkat pertama, analisis univariat ini digunakan untuk menggambarkan insidensi penyakit gagal ginjal kronis di Rumah Sakit Umum Daerah Kabupaten Cirebon. Analisis ini juga dilakukan untuk mendapatkan gambaran secara kualitatif pasien PGK yang menjadi responden berdasarkan latar belakang sosiodemografis dan sosioekonomisnya

2. Analisis bivariat.

Analisis tingkat kedua ini dilakukan untuk mengetahui Odd Ratio (OR) antara berbagai faktor risiko dan PGK stadium-lanjut yang memerlukan hemodialisis.

3. Analisis multivariat.

Pada analisis tingkat ketiga ini dilakukan regresi logaritmik untuk mendapatkan gambaran hubungan antara berbagai faktor risiko (sebagai variabel bebas) dengan terjadinya PGK stadium-lanjut yang memerlukan hemodialisis. 


\section{Hasil dan Pembahasan}

1. Analisis Hubungan Antara Faktor Risiko Dengan PGK

\section{a. Faktor risiko yang tidak dapat dimodifikasi}

1) Jenis Kelamin

Dari analisis data yang diperoleh, jenis kelamin laki laki berisiko sama dengan perempuan terhadap PGK dengan nilai Odds Ratio 95\% CI sebesar $1,000(0,563-1,777)$ sehingga jenis kelamin tidak berpengaruh signifikan $(\mathrm{p}=1,000)$ terhadap kejadian PGK.

2) Umur

Tabel 1 Hubungan antara kelompok umur dengan kejadian PGK

\begin{tabular}{|c|c|c|c|c|c|c|c|c|}
\hline \multirow{2}{*}{ Kategori } & \multicolumn{2}{|c|}{ Kasus } & \multicolumn{2}{|c|}{ Kontrol } & \multicolumn{2}{|c|}{ total } & \multirow{2}{*}{ OR } & \multirow{2}{*}{$\underset{\text { value }}{p}$} \\
\hline & $\mathbf{n}$ & $(\%)$ & $\mathbf{n}$ & $(\%)$ & $\mathbf{n}$ & $\%$ & & \\
\hline \multicolumn{8}{|l|}{ Umur } & \multirow{6}{*}{0,636} \\
\hline$<30$ & 6 & 6,5 & 9 & 9,7 & 15 & 8,1 & 1 & \\
\hline $31-40$ & 16 & 17,2 & 18 & 19,4 & 34 & 18,3 & $0,970(0,268-3,512)$ & \\
\hline $41-50$ & 28 & 30,1 & 24 & 25,8 & 52 & 28,0 & $1,293(0,466-3,590)$ & \\
\hline $51-60$ & 32 & 34,4 & 26 & 28,0 & 58 & 31,2 & $1,697(0,662-4,351)$ & \\
\hline$>60$ & 11 & 11,8 & 16 & 17,2 & 27 & 14,5 & $1,790(0,709-4,518)$ & \\
\hline
\end{tabular}

Penelitian tentang hubungan antara pertambahan umur dengan kejadian PGK di Jepang menunjukkan bahwa proporsi penderita PGK lebih banyak pada kelompok umur yang lebih tua (Nitta et al., 2013). Prevalensi PGK pun meningkat seiring pertambahan Umur (Hill, Fatoba, Oke, Hirst, Callaghan, et al., 2016). Dari data umur responden di atas terlihat $p$ value sebesar 0,636 sehingga disimpulkan bahwa umur tidak signifikan terhadap kejadian PGK.

3) Status Perkawinan

Tabel 2 Hubungan antara status perkawinan dengan kejadian PGK

\begin{tabular}{|c|c|c|c|c|c|c|c|c|}
\hline \multirow{2}{*}{ Kategori } & \multicolumn{2}{|c|}{ kasus } & \multicolumn{2}{|c|}{ kontrol } & \multicolumn{2}{|c|}{ total } & \multirow{2}{*}{ OR } & \multirow{2}{*}{$\begin{array}{c}p \\
\text { value }\end{array}$} \\
\hline & n & $\%$ & $\mathbf{n}$ & $\%$ & $\mathbf{n}$ & $\%$ & & \\
\hline \multicolumn{9}{|l|}{$\begin{array}{l}\text { Status } \\
\text { Perkawinan }\end{array}$} \\
\hline $\begin{array}{l}\text { Belum } \\
\text { Pernah } \\
\text { Kawin } \\
\end{array}$ & 6 & 6,5 & 11 & 11,8 & 17 & 9,1 & $\begin{array}{c}0,468(0,107- \\
2,046)\end{array}$ & \multirow{3}{*}{0,448} \\
\hline Kawin & 80 & 86,0 & 76 & 81,7 & 156 & 83,9 & $\begin{array}{c}0,902(0,290- \\
2,806)\end{array}$ & \\
\hline Janda/Duda & 7 & 7,5 & 6 & 6,5 & 13 & 7,0 & 1 & \\
\hline
\end{tabular}

Dari data umur responden di atas terlihat faktor risiko pada kelompok responden yang belum kawin dan kawin berturut-turut sebesar 0,4 kali dan 0,9 kali dibandingkan dengan janda/duda, namun $p$ value sebesar 0,448 menunjukkan bahwa status perkawinan tidak signifikan terhadap kejadian 
PGK. Odds Ratio dengan nilai $<1$ menunjukkan faktor protektif, dengan nilai OR pada kelompok responden belum pernah kawin lebih rendah daripada kelompok responden yang kawin, kemungkinan berkaitan dengan faktor umur seperti telah dibahas pada bagian sebelumnya, karena kebanyakan kelompok responden yang kawin usianya lebih tua dibanding yang belum kawin.

4) Pendidikan

Tabel 3 Hubungan antara pendidikan responden dengan kejadian PGK

\begin{tabular}{|c|c|c|c|c|c|c|c|c|}
\hline \multirow{2}{*}{ Kategori } & \multicolumn{2}{|c|}{ kasus } & \multicolumn{2}{|c|}{ kontrol } & \multicolumn{2}{|c|}{ total } & \multirow{2}{*}{$\mathbf{O R}$} & \multirow{2}{*}{$\begin{array}{c}\mathbf{p} \\
\text { value }\end{array}$} \\
\hline & $\mathbf{n}$ & $\%$ & $\mathbf{n}$ & $\%$ & $\mathbf{n}$ & $\%$ & & \\
\hline \multicolumn{9}{|l|}{ Pendidikan } \\
\hline $\begin{array}{l}\text { Tidak Sekolah / } \\
\text { Sekolah Dasar }\end{array}$ & 46 & 49,5 & 54 & 58,1 & 100 & 53,8 & $2,130(0,764-5,937)$ & \multirow{3}{*}{0,014} \\
\hline Sekolah Lanjutan & 41 & 44,1 & 24 & 25,8 & 65 & 34,9 & $4,271(1,461-12,481)$ & \\
\hline Akademi/Universitas & 6 & 6,5 & 15 & 16,1 & 21 & 11,3 & 1 & \\
\hline
\end{tabular}

Dari data pendidikan responden di atas terlihat $p$ value sebesar 0,014 sehingga latar belakang pendidikan berpengaruh signifikan terhadap kejadian PGK. OR pada kelompok pendidikan paling tinggi sekolah dasar dan sekolah lanjutan bertururt-turut sebesar 2,1 dan 4,2 kali dibanding dengan pendidikan akademi/universitas. Penelitian di kota Bogor mendapatkan hasil tidak ada hubungan yang signifikan antara pendidikan dengan PGK ( $\mathrm{p}=0,270)$, namun menyatakan hal yang sama terkait faktor protektif dari tingkat pendidikan yang lebih tinggi terhadap penyakit PGK $(\mathrm{OR}=0,485 ; 95 \% \mathrm{CI}=0,216-1,091)$ (Rosiana, 2018).

5) Pekerjaan

Tabel 4 Hubungan antara pekerjaan dengan kejadian PGK

\begin{tabular}{|c|c|c|c|c|c|c|c|c|}
\hline \multirow{2}{*}{ Pekerjaan } & \multicolumn{2}{|c|}{ kasus } & \multicolumn{2}{|c|}{ kontrol } & \multicolumn{2}{|c|}{ Total } & \multirow{2}{*}{ OR } & \multirow{2}{*}{$\begin{array}{c}p \\
\text { value }\end{array}$} \\
\hline & $\mathbf{n}$ & $\%$ & $\mathbf{n}$ & $\%$ & $\mathbf{n}$ & $\%$ & & \\
\hline $\begin{array}{l}\text { Pekerjaan } \\
\text { intelektual }\end{array}$ & 4 & 4,3 & 19 & 20,4 & 23 & 12,4 & $\begin{array}{c}0,261 \\
(0,080- \\
0,854) \\
\end{array}$ & \multirow{4}{*}{0,003} \\
\hline $\begin{array}{l}\text { Pekerjaan } \\
\text { fisik* }\end{array}$ & 49 & 52,7 & 29 & 31,2 & 78 & 41,9 & $\begin{array}{c}2,098 \\
(\mathbf{1 , 0 7 2 -} \\
\mathbf{4 , 1 0 2 )} \\
\end{array}$ & \\
\hline $\begin{array}{l}\text { pekerjaan } \\
\text { dirumah }\end{array}$ & 11 & 11,8 & 9 & 9,7 & 20 & 10,8 & $\begin{array}{c}1.517 \\
(0,554- \\
4,156) \\
\end{array}$ & \\
\hline tidak bekerja & 29 & 31,2 & 36 & 38,7 & 65 & 34,9 & 1 & \\
\hline $\begin{array}{l}* \text { hubungan be } \\
\text { Dari hasil p } \\
\text { ecara bermakna } \\
\text { isik memiliki ris }\end{array}$ & kna & di ata & $=0,0$ & $\begin{array}{l}\text { onder } \\
\text { 3). } \mathrm{P} \\
\text { (OR }\end{array}$ & erj & $\begin{array}{l}\text { an pe } \\
\text { n ya } \\
.95\end{array}$ & $\begin{array}{l}\text { tan berhı } \\
\text { erkaitan } \\
I=1,072\end{array}$ & $\begin{array}{l}\operatorname{gan} \\
\text { gan } \\
\text { 102) }\end{array}$ \\
\hline
\end{tabular}


untuk mengalami PGK dibanding kelompok responden yang tidak bekerja. Penelitian di Turki menunjukkan hasil bahwa jumlah penderita PGK lebih banyak berasal dari pekerja tidak terdidik (unskilled workers) (Kazancioğlu, 2013) yang banyak berasosiasi dengan pekerjaan fisik. Penelitian di Amerika Serikat juga menunjukkan hubungan yang bermakna antara aktivitas fisik yang berat dengan $e G F R$ yang meningkatkan keparahan PGK (Marquis, 2010).

Kaitan antara pekerjaan yang menyangkut aktifitas fisik dengan OR PGK mungkin diakibatkan karena tingginya aktifitas fisik menyebabkan munculnya kebiasaan yang kurang sehat, seperti banyak mengkonsumsi minuman yang mengandung kadar gula dan mineral yang tinggi, atau kebiasaan merokok. Penelitian di Ponorogo juga menunjukkan faktor dominan terjadinya PGK adalah aktifitas berat (68\%) (Isroin, 2014).

6) Pendapatan

Tabel 5 Hubungan antara pendapatan dengan kejadian PGK

\begin{tabular}{|c|c|c|c|c|c|c|c|c|}
\hline \multirow{2}{*}{ Pendapatan } & \multicolumn{2}{|c|}{ kasus } & \multicolumn{2}{|c|}{ kontrol } & \multicolumn{2}{|c|}{ total } & \multirow{2}{*}{ OR } & \multirow{2}{*}{$\underset{\text { value }}{\mathbf{p}}$} \\
\hline & $\mathbf{n}$ & $\%$ & $\mathbf{n}$ & $\%$ & $\mathbf{n}$ & $\%$ & & \\
\hline$\leq$ Rp. 1.000 .000 & 26 & 28,0 & 23 & 24,7 & 49 & 26,3 & $\begin{array}{c}1,837 \\
(0,794-4,247)\end{array}$ & \multirow{6}{*}{0,371} \\
\hline $\begin{array}{l}\text { >Rp. } 1000.000- \\
2.000 .000\end{array}$ & 27 & 29,0 & 22 & 23,7 & 49 & 26,3 & $\begin{array}{c}1,994 \\
(0,861-4,617) \\
\end{array}$ & \\
\hline $\begin{array}{l}\text { >Rp. } 2.000 .000- \\
3.000 .000\end{array}$ & 13 & 14,0 & 7 & 7,5 & 20 & 10,8 & $\begin{array}{c}3,018 \\
(0,995-9,157)\end{array}$ & \\
\hline $\begin{array}{l}>\text { Rp. } 3.000 .000- \\
5000.000\end{array}$ & 8 & 8,6 & 11 & 11,8 & 19 & 10,2 & $\begin{array}{c}1,182 \\
(0,392-3,562)\end{array}$ & \\
\hline > Rp. 5.000 .000 & 3 & 3,2 & 4 & 4,3 & 7 & 3,8 & $\begin{array}{c}1,219 \\
(0,241-6,167) \\
\end{array}$ & \\
\hline Tidak Tahu & 16 & 17,2 & 26 & 28,0 & 42 & 22,6 & 1 & \\
\hline
\end{tabular}

Dari hasil penelitian ini terlihat nilai OR terbesar adalah pada kelompok penghasilan >2.000.000-3.000.000 atau di atas UMR. Hal ini kemungkinan berkaitan dengan pendapatan yang lebih dari pendapatan per kapita di Kabupaten Cirebon (BPS Kabupaten Cirebon, 2018) individu cenderung berubah pola makan dan pola minumnya yang bisa jadi kurang sehat, misalnya banyak mengkonsumsi fastfood, sofdrink, dan sebagainya. Sebagai perbandingan, hasil penelitian di India dan Amerika Serikat juga menunjukkan bahwa sesorang dengan pendapatan yang rendah lebih berpotensi mengalami PGK (Anand et al., 2017) demikian pula di Australia (Johnson, 2012). Peningkatan pendapatan lebih dari dua kali pendapatan perkapita menunjukkan penurunan nilai OR, hal ini mungkin disebabkan karena masyarakat dengan pendapatan yang lebih tinggi memiliki alokasi biaya yang lebih besar untuk menjaga kesehatan. Namun ada juga hasil penelitian yang menunjukkan prevalensi PGK justru lebih tinggi pada kelompok dengan pendapatan yang lebih tinggi (Eva, 2015). Nilai $\mathrm{p}=0,446$ menunjukkan pendapatan tidak berhubungan secara bermakna dengan PGK. 


\section{b. Faktor risiko yang dapat dimodifikasi}

1) Gaya hidup

a) Konsumsi makanan olahan/fast-food/junk-food

Tabel 6 Hubungan antara konsumsi makanan olahan/fast-food/junkfood dengan kejadian PGK

\begin{tabular}{lcccc}
\hline Konsumsi makanan & $\begin{array}{c}\text { kasus } \\
\mathrm{n}(\%)\end{array}$ & $\begin{array}{c}\text { kontrol } \\
\mathrm{n}(\%)\end{array}$ & OR & $\begin{array}{c}\mathrm{p}- \\
\text { value }\end{array}$ \\
\hline $\begin{array}{l}\text { makanan tinggi } \\
\text { lemak dan } \\
\text { garam* }\end{array}$ & $62(66,7)$ & $43(46,2)$ & $\begin{array}{c}7,086 \\
(0,976-8,379)\end{array}$ & 0,008 \\
$\begin{array}{l}\text { makanan tinggi } \\
\text { garam* }\end{array}$ & $46(49.5)$ & $22(23,7)$ & $\begin{array}{c}3,159 \\
(1,686-5,917)\end{array}$ & 0,000 \\
$\begin{array}{l}\text { makanan daging } \\
\text { olahan* }\end{array}$ & $41(44.1)$ & $27(29,0)$ & $\begin{array}{c}1,927 \\
(1,051-3,535)\end{array}$ & 0,048 \\
\hline
\end{tabular}

* hubungan bermakna

Dari tabel di atas terlihat kebiasaan mengkonsumi makanan mengandung lemak dan garam tinggi meningkatkan risiko kejadian PGK sebanyak 7 kali, dengan nilai 0,008 yang berarti ada hubungan bermakna. Makanan dengan kadar lemak yang tinggi dapat memperberat kerja ginjal, sesuai penelitian Wei Ribao di China yang menyatakan bahwa peningkatan kadar lemak dalam darah berefek terhadap insufisiensi ginjal (Ribao et al., 2017).

Konsumsi maknanan tinggi garam berhubungan secara bermakna ( $\mathrm{p}=0,000$ ) pada kejadian PGK dengan meningkatkan risiko 3,1 kali, demikian pula konsumsi daging olahan meningkatkan risiko 1,9 kali dengan $\mathrm{p}=0,048$ yang artinya berhubungan secara bermakna. Tingginya asupan garam berlebih menunjukkan peningkatan eGFR, albuminuria atau proteinuria (Nomura, n.d.) dan peningkatan serum osmolaritas (Kuwabara et al., 2017) sehingga meningkatkan risiko PGK.

b) Konsumsi minuman dan kebiasaan minum

Tabel 7 Hubungan antara konsumsi minuman dan kebiasaan minum dengan kejadian PGK

\begin{tabular}{|c|c|c|c|c|}
\hline Konsumsi minuman & $\begin{array}{l}\text { kasus } \\
\text { n }(\%)\end{array}$ & $\begin{array}{c}\text { kontrol } \\
\text { n }(\%)\end{array}$ & OR & $\begin{array}{c}\text { p - } \\
\text { value }\end{array}$ \\
\hline $\begin{array}{l}\text { minuman soda/gula } \\
\text { mineral tinggi } *\end{array}$ & $42(45,2)$ & $17(18,7)$ & $\begin{array}{c}3,682 \\
(1,892-7,165) \\
\end{array}$ & $\mathbf{0 , 0 0 0}$ \\
\hline $\begin{array}{l}\text { minuman teh, kopi, coklat, } \\
\text { alkohol }\end{array}$ & $54(58,1)$ & $51(54,8)$ & $\begin{array}{c}1,140 \\
(0,638-2,037)\end{array}$ & 0,087 \\
\hline minum air sumur & $75(84,9)$ & $69(74,2)$ & $\begin{array}{c}1,449 \\
(0,725-2,898) \\
\end{array}$ & 0,381 \\
\hline \multicolumn{5}{|l|}{ konsumsi air putih sehari } \\
\hline 1-4 gelas* & $40(43,0)$ & $2(2,2)$ & 34,340 & $\mathbf{0 , 0 0 0}$ \\
\hline
\end{tabular}




\begin{tabular}{ccccc}
\hline & & \multicolumn{3}{c}{$\mathbf{( 7 , 9 7 5 - 1 4 7 , 8 5 8 )}$} \\
\hline $\mathbf{5 - 8}$ gelas* & $\mathbf{2 9}(\mathbf{3 3 , 3})$ & $\mathbf{5 8}(\mathbf{6 2 , 4 )}$ & $\mathbf{0 , 2 7 3}$ & $\mathbf{0 , 0 0 0}$ \\
& & & $(\mathbf{0 , 1 4 9 - 0 , 5 0 2})$ & \\
\hline & & & 0,632 & 0,203 \\
& & & & \\
& & & \\
& & & \\
\end{tabular}

* hubungan bermakna

Pada penelitian ini responden yang sering meminum minuman soda/tinggi gula dan mineral 3,7 kali lebih berisiko terkena PGK dengan nilai $\mathrm{p}=0,000$ yang menunjukkan hubungan bermakna kebiasaan minuman soda/ tinggi gula dan mineral dengan PGK. Penelitian di Bogor juga mendapatakan $O R$ 4,63 $(95 \% C I=2,43-8,82)$ dan nilai $\mathrm{p}=0,000$ pada responden yang sering minum soda (Delima, Andayasari et al., 2014). Hal ini serupa dengan hasil penelitian di London yang menyatakan tingginya konsumsi minuman dengan pemanis buatan (yang biasa ditemukan pada minuman soda/tinggi gula dan mineral) berisiko albuminuria $(O R$ 1,4; $95 \% \mathrm{CI}=1,1-1,7)$ dan berisiko PGK (OR 2,3; $95 \%$ $\mathrm{CI}=1,1-1,69)$ (Sontrop, Dixon, Garg, Buendia-Jimenez, et al., 2013).

Kebiasaan konsumsi minuman teh, kopi, coklat atau alkohol, nilai p > 0,05 yang menunjukkan tidak ada hubungan yang bermakna dengan PGK. Penelitian di Korea menemukan bahwa konsumi kopi sebanyak 1 cangkir atau lebih per harinya dapat berisiko menurunkan GFR sebesar $0,75(-0,84$ hingga $-0,72) \mathrm{mL} / \mathrm{min} / 1,73 \mathrm{~m}^{2}$ per tahun (Jhee et al., 2018). Hal ini menunjukkan risiko konsumi kopi terhadap PGK. Pada penelitian ini kebiasaan konsumsi kopi, teh atau coklat lebih berisiko 1,14 kali terkena PGK.

Penelitian di Sri Lanka menemukan responden yang meminum air sumur lebih berisiko terkena PGK $(O R=4,82 ; 95 \%$ CI $=2,27-10,24)$ (Jayasumana et al., 2015). Hasil penelitian ini juga menunjukkan konsumi air sumur lebih berisiko 1,4 kali terkena PGK, namun nilai $\mathrm{p}<$ 0,05 sehingga tidak memiliki hubungan yang bermakna.

Reseponden yang kurang minum air putih 1-4 gelas sehari 34 kali lebih berisiko terkena PGK dibandingkan dengan mereka yang minum air putih $>8$ gelas per hari, dengan nilai $\mathrm{p}=0,000$ yang menunjukkan hubungan bermakna antara jumlah air putih yang diminum dengan PGK. Konsumsi air putih per hari sebanyak 5-8 gelas menunjukkan nilai OR $<1(0,273)$, yang berarti faktor protektif. Hal ini sama dengan hasil penelitian di Perancis yang menemukan bahwa konsumi air (terutama air putih) dalam jumlah banyak menjadi faktor protektif untuk ginjal (Sontrop, Dixon, Garg, \& Clark, 2013). Penelitian di London juga menunjukkan prevalensi PGK tertinggi ditemukan pada individu yang kurang minum air putih, dan prevalensi itu menurun pada individu yang 
meminum air putih lebih banyak (Sontrop, Dixon, Garg, BuendiaJimenez, et al., 2013).

c) Konsumsi obat, jamu, herbal, multivitamin dan mineral

Tabel 8. hubungan antara konsumsi obat AINS, "stelan", jamu racikan khusus, herbal China dengan kejadian PGK

\begin{tabular}{|c|c|c|c|c|}
\hline Konsumsi & $\begin{array}{l}\text { kasus } \\
\text { n (\%) }\end{array}$ & $\begin{array}{c}\text { kontrol } \\
\text { n }(\%)\end{array}$ & OR & $\begin{array}{c}\mathbf{p} \\
\text { value }\end{array}$ \\
\hline $\begin{array}{l}\text { Obat AINS, "stelan", jamu } \\
\text { racikan khusus, herbal } \\
\text { China }\end{array}$ & $\begin{array}{c}8 \\
(80,0)\end{array}$ & $2(20,0)$ & $4,282(0,884-20,737)$ & 0,104 \\
\hline
\end{tabular}

Pada penelitian ini konsumsi obat AINS, obat stelan, jamu dengan racikan khusus dan herbal China menunjukkan nilai $\mathrm{p}=0,104$ yang berarti tidak ada perbedaan yang bermakna antara kelompok kasus dengan kelompok kontrol. Namun diperoleh OR sebesar 4,282 (95\% CI $=$ 0,884-20,737). Penelitian di Yogyakarta menyatakan riwayat penggunaan obat analgetika dan OAINS memiliki OR 0,0160 $(0,074-$ 0,347) namun $\mathrm{p}<0,05$ (Pranandari, 2015). Vivekanand Jha menyebutkan bahwa obat bahan alam dapat menyebabkan cedera ginjal akut (Acute Kidney Injury, AKI) (Jha \& Rathi, 2008). Purav Mody menyebukan bahwa terdapat hubungan antara AKI dengan gagal ginjal (Jhee et al., 2018) Tsai di Taiwan menyatakan bahwa obat OTC (over the counter, obat bebas) herbal china merupakan faktor risiko yang kuat (OR 10,84; 95\% CI 5,77-20,35) terhadap kejadian ESRD (Tsai, 2009). Laily menemukan hubungan yang bermakna antara minum jamu dengan PGK ( $\mathrm{p}=0,035$ ) (Isroin, 2014) Penelitian di Jakarta juga mendapatakan OR $1,94(1,40-2,70)$ dan nilai $\mathrm{p}=0,000$ pada responden yang sering minum jamu (Delima, Andayasari et al., 2014)

d) Merokok

Dari analisis data yang diperoleh, responden dengan kebiasaan merokok lebih berisiko mengalami PGK dengan OR sebesar 2,517 (95\% CI 1,204 - 5,264) $\mathrm{p}=0,020$, dengan demikian kebiasaan merokok berhubungan secara signifikan dengan PGK. Namun hasil Penelitian di Jakarta menunjukkan kebiasaan merokok tidak berpengaruh secara bermakna (OR 1,39, CI 95\% 0,96-2,00, p=0,08) terhadap PGK.(Delima, Andayasari et al., 2014)

2) Riwayat penyakit

Tabel 9 Hubungan antara riwayat penyakit dengan kejadian PGK

\begin{tabular}{lcccc}
\hline \multicolumn{1}{c}{ Riwayat penyakit } & $\begin{array}{c}\text { Kasus } \\
\mathbf{n}(\boldsymbol{\%})\end{array}$ & $\begin{array}{c}\text { kontrol } \\
\mathbf{n}(\boldsymbol{\%})\end{array}$ & OR & $\begin{array}{c}\mathbf{p} \\
\text { value }\end{array}$ \\
\hline Masalah pada ginjal & $12(12,9)$ & $4(4,3)$ & $\begin{array}{c}3,296 \\
(0,914-9,743)\end{array}$ & 0,067 \\
\hline Hipertensi* & $\mathbf{3 8 ( 4 0 , 9 )}$ & $\mathbf{6 ( 6 , 5 )}$ & $\mathbf{1 0 , 0 1 8}$ & $\mathbf{0 , 0 0 0}$ \\
\hline
\end{tabular}




\begin{tabular}{lcccc}
\hline & & \multicolumn{3}{c}{$\mathbf{( 3 , 9 7 3 - 2 5 , 2 6 1 )}$} \\
\hline Diabetes mellitus* & $\mathbf{1 9}(\mathbf{2 0 , 4 )}$ & $\mathbf{2}(\mathbf{2 , 2})$ & $\begin{array}{c}\mathbf{1 1 , 6 8 2} \\
\mathbf{( 2 , 6 3 6 - 5 1 , 7 8 3 )}\end{array}$ & $\mathbf{0 , 0 0 0}$ \\
\hline $\begin{array}{l}\text { Penyakit jantung dan } \\
\text { pembuluh darah }\end{array}$ & $8(2,2)$ & $2(0,0)$ & $\begin{array}{c}4,282 \\
(0,884-20,737)\end{array}$ & 0,104 \\
\hline
\end{tabular}

* hubungan bermakna

Berdasarkan hasil analisis bivariat ditemukan faktor risiko riwayat penyakit yang memiliki hubungan bermakna dengan PGK yaitu riwayat penyakit hipertensi dan diabetes mellitus dengan nilai $\mathrm{p}$ keduanya sebesar 0,000 dan nilai OR berturut-turut 10,018 (3,973-25,261) dan 11,682 (2,63651,783). Penelitian di Palembang menemukan riwayat penyakit hipertensi sebanyak 57,7\%, riwayat DM sebanyak 25\% (Tjekyan, 2014). Penyakit hipertensi dan diabetes mellitus merupakan faktor risiko terbesar dari PGK di berbagai wilayah di dunia (Jha \& Rathi, 2008) (Isroin, 2014) (Tjekyan, 2014) (Krittayaphong et al., 2017).

Sedangkan riwayat penyakit yang tidak memiliki hubungan bermakna dengan PGK yaitu masalah pada ginjal dan penyakit jantung/pembuluh darah dengan nilai $\mathrm{p}$ berturut-turut sebesar 0,067 dan 0,104. Kedua penyakit ini ditemukan juga pada penelitian di RS Moh. Husni Palembang dimana terdapat penderita PGK yang memiliki masalah pada ginjal sebanyak 18\% (10\% Infeksi Saluran Kemih, 8\% Batu saluran kemih).

\section{Hasil Analisis Multivariat}

Analisis multivariat dilakukan setelah terlebih dahulu dilakukan seleksi terhadap variabel-variabel yang dianalisis secara bivariat. Seleksi ini didasarkan pada nilai signifikansi (nilai p). Suatu variabel akan dianalisis secara multivariat jika memiliki hubungan yang bermakna dengan PGK $(\mathrm{p} \leq 0,05)$ dan variabel potensial $(0,05<\mathrm{p} \leq 0,25)$ (Dr. H. Arif Sumantri, 2011).

Tabel model awal yang berisi 14 variabel yang akan dianalisis secara multivariat tercantum pada Lampiran 1 halaman 66 Tabel V.19. Setelah dilakukan analisis regresi logistik, akan tampil output dari SPSS yang mencantumkan nilai $\mathrm{p}$ dan OR. Dari 14 variabel tadi, satu variabel dengan nilai $\mathrm{p}$ terbesar kemudian dihapus sehingga menyisakan 13 variabel. Analisis regresi logistik dilakukan kembali terhadap 13 variabel tadi, dan dari outputnya kembali dihapus satu variabel dengan nilai $\mathrm{p}$ terbesar sehingga menyisakan 12 variabel. Demikian seterusnya sampai menghasilkan output dengan semua variabel memiliki nilai $p<0,05$ (final model). 
Hasil analisis multivariat diperoleh seperti pada tabel berikut ini.

Tabel 10 Hasil Analisis Multivariat final model

\begin{tabular}{|c|c|c|c|}
\hline Variabel & $\mathbf{O R}$ & $95 \% \mathrm{CI}$ & $\begin{array}{c}\mathbf{p} \\
\text { value }\end{array}$ \\
\hline Pekerjaan* & & & $\mathbf{0 , 0 3 3}$ \\
\hline Pekerjaan intelektual * & 0,104 & $(0,018-0,592)$ & $\mathbf{0 , 0 1 1}$ \\
\hline Pekerjaan fisik & 1,099 & $(0,343-3,522)$ & 0,873 \\
\hline Pekerjaan dirumah & 1,236 & $(0,218-6,992)$ & 0,811 \\
\hline Tidak bekerja & 1 & & \\
\hline Hipertensi* & 46,481 & $(11,444-188,784)$ & 0,000 \\
\hline Diabetes mellitus* & 25,239 & $(3,680-173,093)$ & 0,001 \\
\hline $\begin{array}{l}\text { Konsumsi AINS/obat stelan/jamu } \\
\text { racikan khusus/herbal China* }\end{array}$ & 12,542 & $(1,353-116,267)$ & 0,026 \\
\hline Konsumsi air putih per hari* & & & $\mathbf{0 , 0 0 0}$ \\
\hline 1-4 gelas* & 46,717 & $(7,228-301,926)$ & $\mathbf{0 , 0 0 0}$ \\
\hline $5-8$ gelas & 0,570 & $(0,193-1,678)$ & 0,307 \\
\hline$>8$ gelas & 1 & & \\
\hline $\begin{array}{l}\text { Konsumsi minuman mengandung } \\
\text { gula dan mineral tinggi * }\end{array}$ & 3,808 & $(1,207-12,012)$ & $\mathbf{0 , 0 2 3}$ \\
\hline $\begin{array}{l}\text { Konsumsi maknan mengandung } \\
\text { garam tinggi * }\end{array}$ & 10,317 & $(3,331-31,954)$ & $\mathbf{0 , 0 0 0}$ \\
\hline
\end{tabular}

* hubungan bermakna

Dari hasil analisis multivariat di atas, diperoleh variabel faktor risiko yang memiliki hubungan bermakna ( $\mathrm{p}<0,05)$ dengan kejadian PGK yaitu pekerjaan, riwayat penyakit hipertensi, riwayat penyakit diabetes melitus, konsumsi obat AINS/obat "stelan'/jamu racikan khusus/herbal China, konsumsi air putih, konsumsi minuman mengandung mineral dan gula tinggi, dan konsumsi makanan mengandung garam tinggi.

Penyakit Hipertensi dan diabetes mellitus masih menjadi faktor risiko tertinggi terhadap kejadian PGK di Indonesia (P. D. K. Kesehatan, 2017) (Kementrian kesehatan RI, 2018). Hal yang sama ditemukan juga pada penelitian ini, dengan OR berturut-turut sebesar 46,48 (95\% CI 11,444-188,784) dan 25,24 (95\% CI 3,680-173,093).

\section{Kesimpulan}

Faktor-faktor risiko yang berhubungan secara bermakna dengan kejadian PGK di RSUD Arjawinangun dan Waled Kabupaten Cirebon adalah pekerjaan, riwayat penyakit hipertensi, riwayat penyakit diabetes mellitus, sering mengkonsumsi obat AINS/obat "stelan"/ jamu dengan racikan khusus/herbal barat maupun china, konsumsi air putih, sering mengkonsumsi minuman yang mengandung kadar mineral/gula tinggi, sering mengkonsumsi makanan yang mengandung garam tinggi. 
Dosi Ahmad Yani, Prih Sarnianto dan Yusi Anggriani

\section{BIBLIOGRAFI}

A, Setiawati. (2012). Drug Use in Patients with Renal Failure. CDK-195/ vol. 39 no. 7. www.kalbemed.com

Anand, S., Kondal, D., Montez-rath, M., Zheng, Y., Shivashankar, R., Singh, K., Gupta, P., Gupta, R., Ajay, S., Mohan, V., Pradeepa, R., Tandon, N., Ali, K., Narayan, K. M. V., Chertow, G. M., Kandula, N., Prabhakaran, D., \& Kanaya, A. M. (2017). Prevalence of chronic kidney disease and risk factors for its progression : A crosssectional comparison of Indians living in Indian versus $U$. S . cities. 1-14.

BPS Kabupaten Cirebon. (2018). Kabupaten Cirebon Dalam Angka 2018.

Chasani, S. (2008). Antibiotik Nefrotoksik: Penggunaan Pada Gangguan Fungsi Ginjal.

Cirebon, B. K. (2018). Kabupaten Cirebon Dalam Angka 2018. https://cirebonkab.bps.go.id

Data, P., \& RI, I. K. K. (2017). Situasi penyakit ginjal kronis. Kementerian Kesehatan. Jakarta: Kementerian Kesehatan RI.

Delima, Andayasari, L., Widowati, L., Gitawati, R., Sihombing, M., \& Tjahja, I. (2014). Faktor Risiko Penyakit Ginjal Kronik: Studi Kasus Kontrol di Empat Rumah Sakit di Jakarta Tahun 2014. 17-26.

Dr. H. Arif Sumantri, S. M. (2011). Metodologi Penelitian Kesehatan.

Eva, S. (2015). Faktor Risiko Penyakit Ginjal Kronik Berdasarkan Analisis Crosssectional Data Awal Studi Kohort Penyakit Tidak Menular Penduduk Usia 25-65 Tahun di Kelurahan Kebon Kalapa, Kota Bogor Tahun 2011. 1, 14-17.

Evitasari, D. (2016). Faktor-Faktor yang Berhubungan dengan Perilaku Pemberian Makanan Pendamping ASI Bayi Usia< 6 Bulan. Syntax Literate; Jurnal Ilmiah Indonesia, 1(3), 39-49.

Hill, N. R., Fatoba, S. T., Oke, J. L., Hirst, J. A., Callaghan, A. O., Lasserson, D. S., \& Hobbs, F. D. R. (2016). Global Prevalence of Chronic Kidney Disease - A Systematic Review and Meta-Analysis. 1-18. https://doi.org/10.5061/dryad.3s7rd.Funding

Hill, N. R., Fatoba, S. T., Oke, J. L., Hirst, J. A., O’Callaghan, C. A., Lasserson, D. S., \& Hobbs, F. D. R. (2016). Global prevalence of chronic kidney disease-a systematic review and meta-analysis. PloS One, 11(7), e0158765.

Isroin, L. (2014). Prevalensi faktor risiko gagal ginjal kronik.

Jayasumana, C., Paranagama, P., Agampodi, S., Wijewardane, C., \& Gunatilake, S. (2015). Drinking well water and occupational exposure to Herbicides is associated 
with chronic kidney disease, in Padavi-Sripura, Sri Lanka. 1-10.

Jha, V., \& Rathi, M. (2008). Natural Medicines Causing Acute Kidney Injury. 28(4), 416-428. https://doi.org/10.1016/j.semnephrol.2008.04.010

Jhee, J. H., Nam, K. H., An, S. Y., Cha, M. U., Lee, M., Park, S., Kim, H., Yun, H. R., Kee, Y. K., Park, J. T., Chang, T. I., Kang, E. W., Yoo, T. H., Kang, S. W., \& Han, S. H. (2018). Effects of Coffee Intake on Incident Chronic Kidney Disease: A Community-Based Prospective Cohort Study. American Journal of Medicine. https://doi.org/10.1016/j.amjmed.2018.05.021

Johnson, D. (2012). Risk factors for early chronic kidney disease. Jama, 22(7), 32-41.

Kazancioğlu, R. (2013). Risk factors for chronic kidney disease: An update. Kidney International Supplements, 3(4), 368-371. https://doi.org/10.1038/kisup.2013.79

Kementrian kesehatan RI. (2018). Hasil utama riskesdas 2018. 61. https://doi.org/1 Desember 2013

Kesehatan, K., Penelitian, B., \& Kesehatan, P. (2018). Hasil Utama RISKESDAS 2018. Jakarta [ID]: Balitbangkes Kementerian Kesehatan.

Kesehatan, K., \& RI, K. K. (2013). Riset kesehatan dasar. Jakarta: Badan Penelitian Dan Pengembangan Kesehatan Departemen Kesehatan Republik Indonesia.

Kesehatan, P. D. K. (2017). InfoDATIN, Situasi Penyakit Ginjal Kronis.

Krittayaphong, R., Rangsin, R., Thinkhamrop, B., Hurst, C., \& Rattanamongkolgul, S. (2017). Prevalence of chronic kidney disease associated with cardiac and vascular complications in hypertensive patients: a multicenter, nation-wide study in Thailand. 1-10. https://doi.org/10.1186/s12882-017-0528-3

Kuwabara, M., Hisatome, I., Roncal-jimenez, C. A., Niwa, K., Andres-hernando, A., Jensen, T., Bjornstad, P., Milagres, T., Cicerchi, C., Song, Z., Garcia, G., Sa, L. G., Ohno, M., Lanaspa, M. A., \& Johnson, R. J. (2017). Increased Serum Sodium and Serum Osmolarity Are Independent Risk Factors for Developing Chronic Kidney Disease ; 5 Year Cohort Study. 1-14. https://doi.org/10.1371/journal.pone.0169137

Lifestye.kompas.com. (2016). Peredaran Obat Tak Terkendali. http://lifestyle.kompas.com/read/2016/08/08/170700023/Peredaran.Obat.Tak.Terke ndali

Marquis, H. (2010). The Association Between Physical Activity And Renal Function Heart Rate Recovery as a Predictor of Stroke Incidence in Men with Metabolic Syndrome. 58, 2010.

MEE, A. L. B. (2002). Pharmacotherapy, A Patophysiology Approach. 5th ed. Dipiro $J T$ (Mc Graw-Hill (ed.)). 
Dosi Ahmad Yani, Prih Sarnianto dan Yusi Anggriani

Nitta, K., Okada, K., Yanai, M., \& Takahashi, S. (2013). Aging and chronic kidney disease. Kidney and Blood Pressure Research, 38(1), 109-120.

Nomura, K. (n.d.). Renal function in relation to sodium intake: a\&nbsp;quantitative review of the literature. Kidney International, 1-12. https://doi.org/10.1016/j.kint.2016.11.032

Pranandari, R. (2015). Faktor Risiko Gagal Ginjal Kronik Di Unit Hemodialisis RSUD Wates Kulon Progo. Majalah Farmaseutik, 11(2), 316-320.

Rahadi, M. (2013). Cost Benefit Analysis Hemodialisa dengan Sistem KSO dan dikelola Sendiri di RSUD Subang Tahun 2013. 16-21.

Registry, I. R. (n.d.). 8 th Report $O f$ Indonesian Renal Registry. http://www.indonesianrenalregistry.org/

Ribao, W., Yang, W., \& Tingyu, S. (2017). Dynamic Analysis of Kidney Function and Its Correlation with Nutritional Indicators in a Large Sample of Hospitalized Elderly Patients. 1956-1962. https://doi.org/10.12659/MSM.904374

Rosiana, (2018), Analisis Faktor Risiko dan Komparatif Biaya Pengobatan Penyakit Ginjal Kronis pada Pasien Hemodialisis di RS X:53.

Sontrop, J. M., Dixon, N., Garg, X., \& Clark, W. F. (2013). Association between Water Intake, Chronic Kidney Disease, and Cardiovascular Disease : A Cross-Sectional Analysis of NHANES Data. 434-442. https://doi.org/10.1159/000350377

Sontrop, J. M., Dixon, S. N., Garg, A. X., Buendia-Jimenez, I., Dohein, O., Huang, S. H. S., \& Clark, W. F. (2013). Association between water intake, chronic kidney disease, and cardiovascular disease: A cross-sectional analysis of NHANES data. American Journal of Nephrology, 37(5), 434-442. https://doi.org/10.1159/000350377

Tjekyan, S. (2014). Prevalensi dan Faktor Risiko Penyakit Ginjal Kronik di RSUP Dr. Mohammad Hoesin Palembang Tahun 2012. 4, 275-282.

Su-Ying Tsai, Hung-Fu Tseng, Hsiu-Fen Tan, Yu-Shu Chien, and Chia-Chu Chang, 2009, End-stage Renal Disease in Taiwan: A Case-Control Study. J Epidemiol 2009;19(4):169-176 